\title{
Change of Economic Structure in Jambi Province: Input - Output Model Approach
}

\author{
Ahmad Fauzi $^{1}$, Amri Amir ${ }^{2}$, Junaidi ${ }^{3}$, SyuryaHidayat ${ }^{4}$ \\ ${ }^{1}$ Doctoral Program University of Jambi \\ ${ }^{2,3,4}$ Economic Faculty of Universitas Jambi, Jambi-Indonesia \\ Email: ahmadfauziunja@gmail.com \\ DOI: $10.31364 /$ SCIRJ/v7.i8.2019.P0819685 \\ http://dx.doi.org/10.31364/SCIRJ/v7.i8.2019.P0819685
}

\begin{abstract}
This research aims to analyze change of economic structure in Jambi Province during fiscal centralization and decentralization. Analysis approach is utilizing Input - Output Model. Moreover data is used input - output Jambi Province's data during 1995-2016. Based on research result is obtained the illustration of input - output model approach ranging from shift in composition of raw materials shows there is no change of economic structure in Jambi Province. Meanwhile in Multiplier Score Approach Backward Linkage Effect (BLE) there has been changed of economic structure or structural transformation suitable in the view of Chenery-Syrquin.
\end{abstract}

Keywords: Economic Structure, Input-Output, Multiplier, Leading Sector

\section{INTRODUCTION}

One of purposes in long term from development process in each region, there is change of economic structure signed by shift in agriculture sector's role to industry. In the other words, the role of industry sector becomes mainstay in that economic system. The change of economic structure can be seen from change of contribution to regional economy starting from primary to secondary sector. One of the most celebrated theories associated this change of economic structural is ChenerySyrquin.

In the context of economy of Jambi Province, the role of agricultural sector to economy is still dominant. During 20102017, agricultural sector still dominates in economy of Jambi Province by average proportion approximately $26,97 \%$ per year. Even industry sector was $10,97 \%$ per year (Statistics Bureau, 2018). It means the role of agricultural in forming economic structure is still huge.

Regional autonomy by giving a part of central government's authority to local government by followed fiscal decentralization policy which gives authority to explore income potency and allocate it to unleash change of local economic structural's process. Local change of economic structure leads to unleash regional development process and alleviate some local development problems, such as unemployment and economic growth as well. This research aims to analyze how was the change of economic structure in Jambi Province both centralization and fiscal decentralization period.

\section{CONSEPTUAL AND LITERATURE REVIEW}

\section{a. Theoretical Concept}

Rostow in Todaro and Smith (1996) stated structural change focused attention on mechanism that possible backward countries to transform their domestic economy. From traditional subsistence economic patterns to modern economic, it is more oriented to urban life, and possess manufacture industrial sector more variable and robust service sector. The economy growth has been made structural change of economy. Transformation of structural is change of economic structure process from agricultural sector to industry or service. Every economy will be different tranformed. A regional's economy structure is basic factor that distinguishing a region's situation to another regions. That differences is very closely related with condition and potency a region both in environmental physics and economy social and institutional.

The transformation occured in developing country is transformation from agricultural sector to industry. The change of traditional economic structure to modern. It is defined as a change of economy associated with demand composition, trade, production, and other factors those are needed continuously to increase income and social welfare through enhancement income per capita. Another important aspects from transformation of structural is employment. Clark in Nasoetion (1991) stated that economy growth through transformation process will be achieved through (1) enhancement of employment productivity in each sector, and (2) transferring employment from sector that has low employment productivity to high productivity.

In change of structural model, development is growth and change process will be observed by the same principal characteristics in every country. The difference will be occured in developing countries in taken step and common developing pattern subject to number of factors. The approach that emphasizes pattern, not to theory makes some practician has risk to take wrong conclusion about causality.

Change of structural process leads to step and development pattern can be distinguished due to domestically factors even international. Most of them are out of developing country's control individually. Economists stated that certain patterns in development process are almost in each country. Even though the formula varies. The analyzer of structural change is 
optimistic that economy policy is true and give a profit of economy growth's pattern continuously.

The change of economic structure leads to change of economic structure in long term. That economic structure is industry sector's formation. The change of subsistence economic structure will have industrialization so as the dominant agricultural sector's contribution shifted to manufacture. Factors causing a change of economic structural is very different in each region. The changed of structural will be caused such as policy's effect, change of resources, population, and permanently social condition.

The change of economic structure occured along with GDP Growth whereby is totally gross value added (GVA) from all economic sectors. If in an economy system there are two sectors, viz. Industry (i) and agriculture (p) respectively gross added value ; gross added value (i) and gross added value (p) will be forming GDP, the model is:

$$
\begin{aligned}
& \text { GDP }=\text { GVAi }+ \text { GVAp } \ldots \ldots \ldots \ldots \ldots \ldots \ldots \ldots \ldots \\
& \text { or, } \\
& 1=[a(t) i+a(t) p] \text { GDP } \ldots \ldots \ldots \ldots \ldots \ldots \ldots \ldots
\end{aligned}
$$

Whereby a(t)i and $a(t) p$ is share of respective GDP industry and agriculture; $\mathrm{t}$ shows period. In the preliminary step of development $(\mathrm{t}=0)$, prior to industrialization started $\mathrm{a}(\mathrm{t}) \mathrm{i}<\mathrm{a}(\mathrm{t}) \mathrm{p}$. In development process, there is economic transformation, whereby share of GDP from industry is increasing and share of agricultural's GDP is decreasing.In the last economy development stage $(\mathrm{t}=1)$ score $\mathrm{a}(1) \mathrm{i}>\mathrm{a}(1) \mathrm{p}$ whereby $>\mathrm{a}(1) \mathrm{i}>$ $\mathrm{a}(0) \mathrm{p}$ and $\mathrm{a}(1) \mathrm{p}<\mathrm{a}(0) \mathrm{p}$ (Tambunan, 2006).

\section{Input-Output}

Correlation amongst of input composition and output distribution denote basic theory based on input output model (IO). Put simply, IO model presents information about goods and services transaction and interconnections between units of economy activity in certain period and presented in table. Along the line shows output allocation and the column shows input use in production process (Statistics Bureau, 2000). IO table at the first time was introduced by W. Leontief in 1930s. IO table is a table that gives information about goods and services transaction between production sectors in economy in the form of matrix. The numerical (score) in IO table shows correlation of each sector in regional economy. As quantitative model, IO model is able giving whole description about:

(1) Economic structure encompass output structure and value added of each economy's activity in a region

(2) Intermediate input is use of goods and services by production activities in a region

(3) Procurement structure of goods and services both domestic production and imported goods

(4) Demand structure of goods and services both demand by production and final demand for consumption, investment, and export.

Basic Framework of IO Model consist of 4 (four) quadrants as presented in Picture 1.
Picture 1. Basic Framework of Input-Output Model

\begin{tabular}{||c|c||}
\hline $\begin{array}{c}\text { Quadrant I : } \\
\text { TransactionBetween } \\
\text { Activity(nxn) }\end{array}$ & $\begin{array}{c}\text { Quadrant II : } \\
\text { Final demand } \\
(\mathrm{nxm})\end{array}$ \\
\hline Quadrant III : & Quadrant IV : \\
Primary Input of & Primary Input \\
Production Sector & Final demand \\
(pxn) & (pxm) \\
\hline
\end{tabular}

Source: Statistics Bureau of Republic Indonesia, 2000

Each quadrant is stated in matrix with dimension as like Picture 1. The form of all matrix show IO model framework with statistics outline about goods and services transaction between whole economy activities in certain period. The collection of production sector in Quadrant I, consist of producer group, utilising some resources to produce goods and services, in macro means production system. Sector in this production system is "endogenous". Meanwhile the sectors out of production system, in Quadrant II, III, and IV are "exogenous". IO model distinguish clearly endogenous and exogenous sector. Output, in addition to use in production system in the form of intermediate demand, as well used in out of production system in the form of final demand. Input is used in production system, both there come from internalproduction system viz. intermediate input and out of production system, viz. Primary input (Isard, 1998).

IO analysis model can be used as decision maker in planning sectoral development. IO model produces study about determination of leading sector and can be development focus on economy growth. Integration of economy in IO model reflects correlation or intersectoral whereby correlation of mutual dependent one and other.

In eachrow denotes number of sales in detailfrom a sector that published in seller column to various sectors that written in label below the buyer. Therefore a sector does not sell its godos to all existing sectors, in generally the zero number in a row in IO table. And the column in IO table records some purchases carried out by a sector to goods and services which produced by various sectors in that área. If the numerical or scores in column with numerous of zero number, itmeans sector does not always purchase goods and services from whole sectors in that country (Nazara, 1997).

Aside from inter sectoral's transaction, there are some transactions noted in IO table. Firms in a sector sell the proceeds to consumer (households), government, and foreignfirms. Moreover, a part of production is become part of investment and other sectors. The sale just mentioned will becollected into a scale, mentioned 'last consumption'. In purchasing case, asidefromgoodsand services from various sectors, firms should need employment's service and give compensation to capital owner. Fees services to employment and owner capital isfees to 'value added'. On the other hand, firms must purchasegoods and services from abroad, in the other words, firms import goods and services. Transaction of imported goods and services noted in 'impor' line. Put simply, simplification from IO table, can be seen in Table 1. 
Tabel 1.Simplification ofInput Output

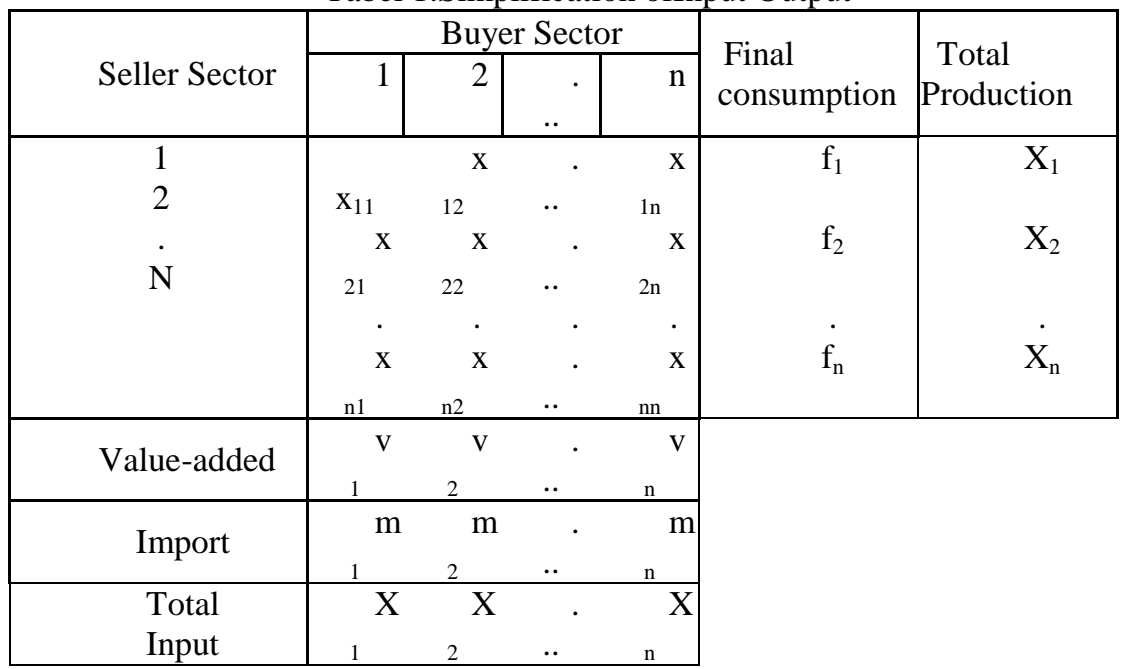

Source: Statistics Bureau, 2000

Based on IO Table in Table 1 we can make two balanced equations:

$$
\begin{aligned}
& \text { Row }: \sum_{j=1}^{n} x_{i j}+f_{i}=X_{i} \quad \forall i=1, \ldots, n \\
& \text { Column : } \sum_{i=1}^{n} x_{i j}+v_{j}+m_{j}=X_{j} \quad \forall j=1, \ldots, n
\end{aligned}
$$

Wherebyxijisvalue of goods and servicesflowfrom sector ito sector $j . F i$ is final total consumption, vjisvalueadded, and mjisimport. The definition of a balanced sheet is the number of outputs equal to the number of inputs. Interindustry flows can be transformed into coefficients by assuming that the sum of various purchases is fixed for a level of total output (in other words, there are no economies of scale) and there is no possibility of substitution between an input raw material and other input materials (with in other words, input raw materials are bought in a fixed proportion). These coefficients are:

$$
a_{i j}=x_{i j} / X_{j}
$$

or

$$
x_{i j}=a_{i j} X_{j}
$$

By combining both equations above, obtained:

$$
\sum_{j=1}^{n} a_{i j} X_{j}+f_{i}=X_{i} \quad \forall i=1, \ldots, n
$$

In matrixnotation, theequation can be written as follows:

$$
A X+f=X
$$

Whereby:

$$
a_{i j} \in A_{n x n} ; f_{i} \in f_{n x 1} ; \text { dan } X_{i} \in X_{n x 1} .
$$

Bymanipulatingtheequationabove, thebasiccorrelation of IO tableisobtained:

$$
(\mathrm{I}-\mathrm{A})-1 \mathrm{f}=\mathrm{X}
$$

Whereby $(I-A)^{-1}$ is Leontief Inverse Matrix (Leontief, 1986). This matrix contains important information about how increases the production of one sector to develop another sectors.

Due to each sector has different pattern (purchase and sale with other sectors), that the effect of production change a sector to another total production's sectors are different. Leontief inverse matrix summarizes all the effects of changing a sector's production on the total production of other sectors into coeffcients is called multiplier. This multiplier is numerical seen in Leontief Inverse Matrix $(I-A)^{-1}$. Conceptually, there are 3 (three) basic assumptions underlying the preparation of IO models and economic models derived from IO table (Statistics Bureau, 2000), among others, departing from the following assumptions: (a). The assumption of homogeneity, which requires that each sector only produce one type of output with a single input structure and there is no automatic substitution between various sectors, (b) The assumption of proportionality, which requires that in the production process the relationship between input and output is a linear function, viz. each type of input absorbed by a particular sector increases or decreases proportionally (proportionally) to the increase or decrease in sector output produced, (c) Additively assumption, which is an assumption that states that the total effect of the implementation of production in various sectors is produced by each sector separately. It means that outside the Table I-O system all outside influences are ignored.

With these assumptions, the I-O analysis model has limitations, including: because the input-output ratio is constant throughout the analysis period, producers cannot adjust their input changes or change production processes. In addition, this fixed relationship means that if the input of a sector is multiplied, the output will be twice as well. This assumption rejects the influence of technological change or productivity, which means that changes in quantity andprice of inputs are proportional to changes in quantity and price of output (Nazara 1997).

\section{III.PREIVIOUS RESEARCH}

1. Saraan (2006) utilising key data indicators of developing Asian and Pacific countries in 1980-2004 by using the Ordinary Least Square method to conclude that there has been a structural transformation of the economy in Indonesia 
in the observation period in the form of transforming the agricultural sector into the industrial sector.

2. Fabiomarta (2004) with the same method of developing the Chenery-Syrquin Model for Indonesia during 1977-2002 found a tendency to decrease the role of the primary sector. Meanwhile, Hill (1996) described a structural transformation during 1966-1992 with the object of Indonesian economic research. The results of his research showed that the transformation that occurred in Indonesia during these periods were considered too fast. This is indicated by the contribution of the agricultural sector to the Gross Domestic Product (GDP) which has shrunk to less than half since 1966, and in 1992 the contribution was only $36 \%$. This decrease was followed by an increase in the contribution of the industrial sector, whose contribution at that time was 35\% higher than the value in the mid-1960s.

3. Nazara and Amir (2005) usedInput Output Model stated during period 1994-2000 there have been a change in the structure of the economy of East Java, which is indicated by changes in economic landscape visualization using the Multiplier Product Matrix. This change indicates a change in sectoral influence in the economy or change the role of important sectors for the economy in 1994 and 2000. Changes in the economic structure of East Java from 1994 to 2000 were still too small, but there had been changes in the contribution of economic sector output, changes in leading sectors and correlation between economic sectors.

4. Subagiyo (2009) concluded that in period 1993-2006 there had been a shift in the economic structure of Jambi Province which was quite large due to the rapid growth in the mining and quarrying sector moreover services sector.

5. Budi Kurniawan (2015) analyzed the changes in the economic structure of Jambi Province by using the Product Matrix Multiplier Approach concluded that there had been a fundamental structural change in economy of Jambi Province along with economic growth. The change in structure has changed Jambi's economic style from the dominance of the primary sector to tertiary sector and de-industrialization has taken place. Moreover,Romli (2016) who observed structural transformation factors and its effect on income disparity in Madura District showed that the GDP of the agricultural sector had a significant effect and negative parameters on income disparities, it means the enhancement of GDP's agricultural sector contribution would be effective in reducing income distribution. On the contrary, the GDP per province variable of the industrial sector and the significant influence services have positive parameters, mean the enhancement ofGDP per province's contribution of industrial sector and services will increase the income distribution gap.

\section{IV.RESEARCH METHOD}

To analyze changeof economic structure in Jambi Province, the Regional Input-Output (IO-R) model is used. The analysis carried out is not only limited to 4 (four) groups of sectors as can only be observed (agriculture, mining, industry, and services), but there are 23 economic sectors which also involve variable wages, business surpluses, indirect taxes, household consumption, government consumption, investment, exports and imports. Furthermore, structure of Jambi Province's IO-R.

To observe change of economic structure, at least 2 (two) periods of IO-R is required. In this study, Jambi Province IO-R analyzed was backcasting IO-R to 1995 which represented the period before the implementation of fiscal decentralization, and IO-R updating to 2016 which shows the period of implementation of fiscal decentralization.

\section{a. Input Coefficient}

Each input coefficient is calculated from the transaction table (base table) in the following way:

$$
\begin{aligned}
& a i j=\frac{x_{i j} j}{x_{j}} . \\
& v j=\frac{V_{j}}{x_{j}} . \\
& \text { whereby; }
\end{aligned}
$$

\section{a. Output Multiplier Matrix}

There are two types of MPO which can be derived from the transaction table on the basis of producer prices. First, MPO whereby the imports are needed as Exogenous Variables free from others (imports of each sector are considered proportional to the level of use of the sector concerned). The first type of MPO is the (I-Ad $)^{-1}$ while the second is the matrix (I-Ad $)^{-1}$. The $(\mathrm{I}-\mathrm{Ad})^{-1}$ matrix is derived from the transaction table with noncompetitive import treatment, while the ((I-Ad) $)^{-1}$ matrix from the transaction table is treated competitively with imports. The two functions of the equation using both MPOs are:

$$
\begin{aligned}
& \mathrm{X}=(\mathrm{I}-\mathrm{A})^{-1}(\mathrm{~F}-\mathrm{M}) \text { and } \\
& \mathrm{X}=\left(\mathrm{I}-\mathrm{A}_{\mathrm{d}}\right)^{-1} \mathrm{~F}^{\mathrm{d}} \ldots \ldots \ldots \ldots \ldots \ldots \ldots \ldots \\
& \text { Whereby; } \\
& \mathrm{X}=\text { output matrix } \\
& \mathrm{I}=\text { identity matrix } \\
& \mathrm{A}=\text { Total Input coefficient matrix } \\
& \mathrm{Ad}=\text { Domestic Input coefficient matrix }
\end{aligned}
$$

$$
\begin{aligned}
& M=\frac{1}{Q}\left\|g_{i_{\bullet} g_{\bullet} j}\right\|=\frac{1}{Q}\left(\begin{array}{c}
g_{g_{\bullet}} \\
g_{2 \bullet} \\
\vdots \\
g_{n \bullet}
\end{array}\right)\left(\begin{array}{llll}
g_{\bullet 1} & g_{\bullet 2} & \ldots & g_{\bullet n}
\end{array}\right) \\
& \mathrm{F}=\text { total final demand matrix } \\
& \mathrm{Fd}=\text { matrix of domestic final demand } \\
& \mathrm{M}=\text { Import Matrix }
\end{aligned}
$$

\section{b. Power Dispersion Index and Degree of Sensitivity}

Rasmussen (1956) has provided two types of index sizes to see the future and backward linkages of a sector in an economy, through (1) power of dispersion, and (2) sensitivity of dispersion. With these two indices we can make a comparison of the degree of inter-sectoral linkages, which sectors can later be determined as key sectors or leading sector in economic development. Statistics Bureau (2000) gived terms to each of these index sizes with the name of the Power Dispersion Index (IDP) and the 
Sensitivity Dispersion Index (IDK), where the following formula is used to measure it.

$$
\begin{aligned}
& \alpha_{j}=\frac{\sum_{i=1}^{n} g_{i j}}{\frac{1}{n} \sum_{i} \sum_{j} g_{i j}} \\
& \beta_{i}=\frac{\sum_{j=1}^{n} g_{i j}}{\frac{1}{n} \sum_{i} \sum_{j} g_{i j}}
\end{aligned}
$$

Whereby $\alpha j$ shows the IDP of sector $\mathrm{j}$ in economy, and $\beta_{i}$ is the IDK of sector $i$. Whereasgij is an element in the Leontif inverse matrix that is built from the equation $\mathrm{G}=(\mathrm{I}-\mathrm{A})^{-1}$.

The Power of Dispersion and Sensitivity of dispersion degree are the ratio of impacts, both backward and forward, to the average of all sector impacts, so that each of these values is often referred to as the backward linkage effect ratio and forward linkage effect ratio. If the value of the power dispersion index of sector $\mathrm{j}$ is greater than one, $\alpha \mathrm{j}>1$, this is a relative sign of the final demand of sector $j$ in stimulating production growth greater than average, so that this sector is a strategic sector in spurring economic growth. Likewise for sector $\mathrm{i}$ which has a spread index greater than one, $\beta \mathrm{i}>1$, can be classified as a strategic sector, because in relative terms it can meet final demand as much as above the average ability of other sectors.

\section{c.Change of Structural Analysis}

Jiemin and Planting (2000) inDaryanto and Hafizrianda (2010) used anMultiplier Product Matrix or MPM to see the impact of a sector as a whole in an economy. This MPM can capture the influence of a sector based on backward and forward linkages, which at the same time can explain the relationship between a sector and other sectors. For instance Q shows the number of all elements in the Leontif inverse matrix, which are determined by the formula:

$$
Q=\sum_{i=1}^{n} \sum_{j=1}^{n} g_{i j}
$$

Then MPM can be determined by whereby;

$$
\begin{gathered}
g_{\bullet j}=\sum_{i=1}^{n} g_{i j} \\
g_{i \bullet}=\sum_{j=1}^{n} g_{i j} .
\end{gathered}
$$

Through MPM analysis, we can observe how the condition of economic structure an area from one period and another, which means that it can be seen how the structural changes occured every time. This analysis is very important as one of the bases for establishing sectoral development strategies in the future, especially for the short term.

\section{d. Impact Model of IO-R Simulation}

One of the advantages of IO-R model is it can determine changes ofsectoral output when the economic value of final demand factors is determined. Including changes of income, value added and labor can also be estimated. Put simply, the formula used to analyze the impact on the macroeconomic variables of the region is as follows:

$$
\begin{aligned}
& \mathrm{X}=(\mathrm{I}-\mathrm{A})^{-1} \text {. FD ................... [19] } \\
& \mathrm{L}=1 .(\mathrm{I}-\mathrm{A})^{-1} . \mathrm{FD} \ldots \ldots \ldots \ldots \ldots \ldots \ldots \ldots \ldots \ldots \ldots \ldots
\end{aligned}
$$

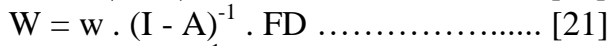

$$
\begin{aligned}
& \mathrm{V}=\mathrm{v} \cdot(\mathrm{I}-\mathrm{A})^{-1} \text {. FD .............. [22] } \\
& \text { Whereby: } \\
& \mathrm{X} \text { :is output ; } \mathrm{L} \text { : isLabor } \\
& \mathrm{W} \text { : is income; } \mathrm{V} \text { : isvalue added } \\
& \mathrm{W} \text { : iswages coefficient: 1: isLabor coefficient } \\
& \mathrm{V} \text { isvalue added coefficient } \\
& \text { FD is Final Demand (I - A })^{-1} \text { isLeontif Inverse Matrix }
\end{aligned}
$$

In IO-R structure, as explained above the FD's component (Final Demand) is an equation: $\mathrm{FD}=\mathrm{C}+\mathrm{G}+\mathrm{I}+\mathrm{X}-\mathrm{M}$, whereby $G$ is government expenditure which is a routine expenditure consisting of civil servantexpenditure (BP) and goods and services (BBJ) expenditure. Whereas $\mathrm{I}$ is a regional investment consisting of private investment (IS) and government investment stated in the form of capital expenditure (BM). Based on this idea, FD equation can be derived in the context of government policy:

$$
\begin{aligned}
\mathrm{FD} & =\mathrm{C}+\mathrm{G}+\mathrm{I}+\mathrm{X}-\mathrm{M} \\
& =\mathrm{C}+(\mathrm{BP}+\mathrm{BBJ})+(\mathrm{IS}+\mathrm{BM})+\mathrm{X}-\mathrm{M} \\
& =\mathrm{BP}+\mathrm{BBJ}+\mathrm{BM}+(\mathrm{C}+\mathrm{IS}+\mathrm{X}-\mathrm{M}) \\
& =\mathrm{BP}+\mathrm{BBJ}+\mathrm{BM}+\mathrm{PL} \ldots \ldots \ldots \ldots \ldots \ldots[23]
\end{aligned}
$$

Whereby PL is another expenditure group covering Household Consumption (C), Private Investment (IS), Export $(\mathrm{X})$ and Import $(\mathrm{M})$ expenditures. If it is assumed that the PL does not change, BP, BBJ and BM both change separately each or simultaneously, the values of $\mathrm{X}$ (output), L (labor), W (income) and V (added value) can be known as a result of government expenditure policies (see again equations 19 to 23). Which is changes of BP, BBJ and BM in simulation with IO-R model still use previous scenarios are applied in simultaneous econometric models.

The advantages of the input-output model simulation can produce change of sectoral value amount of 23 economic sectors for respective of macroeconomic variables, such as output, income, labor and value added. Due to IO-R was built to consist of two periods, 1995 and 2016, it was further observed there were changes in sectoral structure between of two periods. The limitations are simulations can only be carried out based on moderate estimation values which are not based on data time histories, and cannot involve other variables beyond the Final Demand factor.

\section{RESEARCH RESULT}

The GDP per Province structure according to business fields in Jambi Province from 2010-2017 recorded 17 main business fields whereby the agricultural, forestry and fisheries business fields dominated each year with approximately $29.41 \%$ in 2017 with an average of $26.97 \%$ and this is higher compared to other business fields and every year. 
Table 2.GDP per Province StructureAccordingTo Business Fieldsin Jambi Province During 2010-2017(\%)

\begin{tabular}{|l|r|r|r|r|r|r|r|r|c|}
\hline \multicolumn{1}{|c|}{ Main Economy Sectors } & $\mathbf{2 0 1 0}$ & $\mathbf{2 0 1 1}$ & $\mathbf{2 0 1 2}$ & $\mathbf{2 0 1 3}$ & $\mathbf{2 0 1 4}$ & $\mathbf{2 0 1 5}$ & $\mathbf{2 0 1 6}$ & $\mathbf{2 0 1 7}$ & Average \\
\hline A. Agriculture, Forestry, and & 26.07 & 26.2 & 24.19 & 25.63 & 26.22 & 28.24 & 29.8 & 29.41 & 26.97 \\
\hline Fishery & & & & & & & & & \\
\hline B. Mining and Quarrying & 26.77 & 26.83 & 27.3 & 26.16 & 24.48 & 19.01 & 16.6 & 17.66 & 23.10 \\
\hline C. Industry & 11.43 & 11.15 & 11.27 & 11.15 & 10.94 & 11.05 & 10.48 & 10.28 & 10.97 \\
\hline D. Procurement, Electricity, Gas & 0.04 & 0.04 & 0.05 & 0.04 & 0.05 & 0.05 & 0.06 & 0.06 & 0.05 \\
\hline $\begin{array}{l}\text { E. Water, Management Trash, } \\
\text { Waste, andRecycle }\end{array}$ & 0.16 & 0.15 & 0.14 & 0.14 & 0.14 & 0.14 & 0.14 & 0.14 & 0.14 \\
\hline F. Construction & 5.88 & 5.74 & 6.37 & 6.78 & 7.1 & 7.23 & 7.03 & 6.96 & 6.64 \\
\hline $\begin{array}{l}\text { G. Large and Retail Trade; Car } \\
\text { Repair and Motorcycle }\end{array}$ & 8.47 & 9.04 & 9.28 & 9.27 & 9.78 & 11.12 & 12.16 & 12.12 & 10.16 \\
\hline H. Vehicle and Storage & 3.02 & 2.9 & 2.95 & 2.91 & 2.95 & 3.17 & 3.35 & 3.26 & 3.06 \\
\hline $\begin{array}{l}\text { I. Accomodation Supply and } \\
\text { Foods and Beverage }\end{array}$ & 0.94 & 0.95 & 1 & 1.02 & 1.1 & 1.15 & 1.18 & 1.2 & 1.07 \\
\hline $\begin{array}{l}\text { J. Information and } \\
\text { Communication }\end{array}$ & 3.26 & 3.09 & 3.16 & 3.07 & 3.07 & 3.47 & 3.76 & 3.87 & 3.34 \\
\hline $\begin{array}{l}\text { K. Financial Service and } \\
\text { Insurance }\end{array}$ & 1.97 & 2.21 & 2.41 & 2.5 & 2.45 & 2.43 & 2.53 & 2.45 & 2.37 \\
\hline L. Real Estate & 1.59 & 1.59 & 1.57 & 1.49 & 1.45 & 1.56 & 1.59 & 1.55 & 1.55 \\
\hline M.N. Firms Service & 1.2 & 1.13 & 1.15 & 1.09 & 1.09 & 1.16 & 1.21 & 1.2 & 1.15 \\
\hline $\begin{array}{l}\text { O. Government Administration, } \\
\text { Security and Social Guarantee }\end{array}$ & 3.56 & 3.64 & 3.58 & 3.48 & 4.16 & 4.88 & 4.71 & 4.48 & 4.06 \\
\hline P. Educational Service & 3.56 & 3.42 & 3.64 & 3.41 & 3.12 & 3.3 & 3.34 & 3.3 & 3.39 \\
\hline Q. Medical Service and Social & 1 & 0.93 & 0.97 & 0.94 & 1.02 & 1.08 & 1.1 & 1.09 & 1.02 \\
\hline R.S.T.U. Other Services & 1.08 & 0.99 & 0.96 & 0.91 & 0.89 & 0.96 & 0.97 & 0.96 & 0.97 \\
\hline GDP in Province & $\mathbf{1 0 0}$ & $\mathbf{1 0 0}$ & $\mathbf{1 0 0}$ & $\mathbf{1 0 0}$ & $\mathbf{1 0 0}$ & $\mathbf{1 0 0}$ & $\mathbf{1 0 0}$ & $\mathbf{1 0 0}$ & $\mathbf{1 0 0 . 0 0}$ \\
\hline
\end{tabular}

Source : Statistics Bureau, (Processed, 2018)

Whereas for mining and quarrying in 2017 is 19.01 percent, this value greatly decreased from 2010 approximately 26.77 percent and decreased to 2017 with an average of 23.10 percent. And the lowest level of business is in the procurement of electricity and gas, whereby in the last seven years the business field experienced a stability of 0.4 to 0.5 percent with an average of 0.5 percent. In the meantime, the GDP structure according to expenditure in Jambi Province in 2010 - 2017 whereby there are four components of expenditure, the expenditure component is more dominant in export expenditures whereby it experiences fluctuated each year.

Table 3.GDP in Province Structure According To Expenditure in Jambi Province During 2010-2017(\%)

\begin{tabular}{|l|c|c|c|c|c|c|c|c|c|c|}
\hline \multicolumn{1}{|c|}{ Expenditure } & 2010 & 2011 & 2012 & 2013 & 2014 & 2015 & 2016 & 2017 & Average \\
\hline Households Consumption & 30.01 & 30.98 & 30.75 & 30.90 & 30.44 & 30.09 & 30.54 & 29.90 & 30.45 \\
\hline $\begin{array}{l}\text { Non-Profit Private Institution } \\
\text { Consumption }\end{array}$ & 0.29 & 0.31 & 0.32 & 0.33 & 0.36 & 0.36 & 0.35 & 0.34 & 0.33 \\
\hline Government Expenditure & 5.36 & 5.59 & 5.67 & 5.73 & 5.64 & 5.37 & 4.97 & 4.82 & 5.39 \\
\hline Investment & 15.11 & 12.28 & 17.27 & 16.51 & 17.02 & 15.90 & 16.21 & 16.07 & 15.80 \\
\hline Export & 49.24 & 50.83 & 45.98 & 46.53 & 46.55 & 48.28 & 47.92 & 48.88 & 48.03 \\
\hline Last Final Demand & 100.00 & 100.00 & 100.00 & 100.00 & 100.00 & 100.00 & 100.00 & 100.00 & 100.00 \\
\hline
\end{tabular}

Source: Statistics Bureau of Jambi Province, 2018 (Processed).

\section{IV.ANALYSIS OF INPUT - OUTPUT AND CHANGE OF ECONOMIC STRUCTURE \\ Input-Output Macro Model In Jambi Province 1995 and 2016}

One of tools used in this study to capture the impact of government expenditure on regional economy and the comprehensive changes in Jambi's economic structure is InputOutput Regional (IO-R). As a quantitative model, IO-R is able to provide a comprehensive picture of the interrelationships between sectors described through the output structure, value added, supply and demand for goods / services.

Jambi Province's IO-R Structure developed in this study consist of 23 productive economic sectors, and involved 9 (nine) exogenous macroeconomic variables, like wages, business surpluses, depreciation, indirect taxes, household consumption, government consumption, investment, exports and import. IO-R Jambi Province which was built in this study consisted of two different time points, in 1995 and 2016. The two-time choices 
that were very far different were based on these considerations: (1) the year before the 1998 crisis was assumed to be more normal and more representative to explain the phenomenon of Jambi economy at the time of the enactment of the fiscal centralization policy, therefore it was established in 1995 as the initial period of IO-R representing the economic condition of Jambi in the period of fiscal centralization ;; (2) simultaneous local elections in Jambi Province were held in 2015, with the decision set at the end of 2015 to lead Jambi Province during the period 2016-2021, based on this consideration finally 2016 was chosen as the second IO-R period representing the period of implementation of fiscal decentralization. Thus in this discussion the table of economic transactions used is divided into 2 (two) periods, namely Jambi Province IO-R 1995 and Jambi Province IO-R 2016. Whereby in macro, which consists of 9 production sectors and 2 (two) exogenous variables, Jambi Province IO-R can be noted in the following Tables 5.17 and 5.18.

Prior to analyze of structural changes, the results of statistical tests of the difference in average input-output values are first delivered between 1995 IO-R and 2016 IO-R, with the aim of testing the value of transactions observed in 1995 and 2016 statistically different so that changes Jambi Province's IO-R structure between the two periods is valid to be measured. The results of the mean difference test are referred to as follows.

Table 4. Statistics Test Average Different Input-Output Transaction Value in Jambi Province Amongst of 1995-2016

\begin{tabular}{|l|r|r|r|r|r|}
\hline \multirow{2}{*}{ Tested Variable } & \multicolumn{3}{|c|}{$\begin{array}{c}\text { Average } \\
\text { (in billions rupiah) }\end{array}$} & \multicolumn{2}{c|}{$\begin{array}{c}\text { Test Result of Two } \\
\text { Different in Average }\end{array}$} \\
\cline { 2 - 6 } & \multicolumn{1}{|c|}{$\mathbf{2 0 1 6}$} & \multicolumn{1}{c|}{$\mathbf{1 9 9 5}$} & \multicolumn{1}{c|}{ Difference } & \multicolumn{1}{c|}{ t-stat } & p-value \\
\hline TOTAL INPUT & $23,799.27$ & 242.13 & $23,557.14$ & 3.6863 & 0.0006 \\
\hline a. Intermediate input & $16,293.96$ & 87.67 & $16,206.30$ & 3.3327 & 0.0015 \\
\hline b. Primary Input & $7,505.31$ & 154.47 & $7,350.84$ & 3.7002 & 0.0006 \\
\hline 1. Wages & $2,369.87$ & 41.68 & $2,328.19$ & 2.7875 & 0.0054 \\
\hline 2. Business Surpluses & $4,645.52$ & 99.71 & $4,545.82$ & 3.4515 & 0.0011 \\
\hline 3. Depreciation & 304.71 & 9.16 & 295.55 & 3.4681 & 0.0011 \\
\hline 4. Indirect Tax Netto & 185.21 & 3.93 & 181.28 & 2.7187 & 0.0063 \\
\hline TOTAL OUTPUT & $23,799.27$ & 242.13 & $23,557.14$ & 3.6863 & 0.0006 \\
\hline a. Intermediate Output & $16,293.96$ & 87.67 & $16,206.30$ & 3.3237 & 0.0015 \\
\hline b. Final Demand & $11,122.18$ & 223.56 & $10,898.62$ & 3.5434 & 0.0009 \\
\hline 1. Households Consumption & $3,395.04$ & 111.39 & $3,283.65$ & 3.1301 & 0.0024 \\
\hline 2. Government Expenditure & 640.03 & 12.09 & 627.94 & 2.0283 & 0.0274 \\
\hline 3. Investment & $2,127.08$ & 61.23 & $2,065.85$ & 1.4779 & 0.0768 \\
\hline 4. Export & $4,960.03$ & 38.85 & $4,921.18$ & 2.3392 & 0.0144 \\
\hline c. Import & $3,616.87$ & 69.09 & $3,547.78$ & 4.7474 & 0.0000 \\
\hline Dat Processed. 2019 & & & & & \\
\hline
\end{tabular}

Source: Data Processed. 2019

The results of the statistical tests presented in Table 4 above, confirm that all the components of the Jambi IO-R 2016 have a significantly different average value with Jambi IO-R in 1995. It can be observed in all p-value numbers of different tests 2 average less than 0.05 (95\% confidence level), or $0.10(90 \%$ confidence level). Based on this information it was finally decided that the structure of the Jambi IO-R was significantly different from the Jambi IO-R 2016, so that the comparison between the two was relevant.

Changes of IO-R structure compared broadly include 2 (two) values, namely the value of proportion and multiplier. The value of the proportion consists of changes in GDP structure according to income and expenditure, sectoral GDP structure, sectoralinput-output, and sectoral performance. Whereas in the multiplier value, the compared structure includes changes in the structure of the leading sector, economy landscape, and sources of growth in a sectoral manner. All of this is conveyed in the following discussion.

Change of Input-Output Structure According To Sectoral

The next important structure is analyzed in the context of economic transactions in the matrix IO-R is the intermediate input structure, intermediate output, and total sectoral inputoutput. Intermediate input which is usually referred to as raw material used to produce production output, can be disaggregated or specified according to sector. Likewise with the intermediate output which shows where the output of production is used to produce the next production output, it can be traced according to economic sectors. For more details, see Table 4 and 5 below. 
Table 5.

Change of Input Structure By Sectoral in Jambi ProvincePeriod 1995 and 2016(\%)

\begin{tabular}{|c|c|c|c|}
\hline \multirow{2}{*}{ Sector } & \multicolumn{3}{|c|}{ Intermediate Input } \\
\hline & 1995 & 2016 & $\Delta \mathbf{I A}$ \\
\hline Food Crops and Horticulture & 8.35 & 0.16 & -8.19 \\
\hline Plantation Plant & 10.58 & 25.43 & 14.84 \\
\hline Live Stock and Derivation Result & 1.22 & 0.13 & -1.09 \\
\hline Forestry and Logging & 5.37 & 0.22 & -5.15 \\
\hline Fishery & 1.54 & 4.85 & 3.31 \\
\hline Mining and Quarrying & 0.72 & 1.52 & 0.80 \\
\hline Coal Industry and Oil and Gas Refinery & 0.00 & 1.55 & 1.55 \\
\hline Food Industry, Beverageand Tobacco & 3.09 & 14.93 & 11.85 \\
\hline Textil, Leather Goods, Footwear & 0.11 & 0.45 & 0.35 \\
\hline $\begin{array}{l}\text { Wood Industry, Goods From WoodandCork,danHandmadeSouvenirfrom Bamboo and } \\
\text { Rattan }\end{array}$ & 24.40 & 2.61 & -21.79 \\
\hline Pulp industry, Goods from Pulp; Printing and Recording Media & 1.31 & 1.38 & 0.07 \\
\hline Chemistry, PharmacydanTraditional Medicine & 0.05 & 0.01 & -0.04 \\
\hline Rubber Industry, Goods from Rubber and Plastic & 0.69 & 3.79 & 3.09 \\
\hline Non-Metal Quarrying and Base Metal & 0.29 & 0.77 & 0.47 \\
\hline Metal Industry;Computer, Electronic, Optic; and Electricity Tools & 0.01 & 1.30 & 1.29 \\
\hline Another Industries & 0.11 & 0.52 & 0.41 \\
\hline Procurement for Electricity, Gas, Water, and Management of Trash, Waste, and Recycle & 1.76 & 0.58 & -1.18 \\
\hline Construction & 4.24 & 4.80 & 0.55 \\
\hline Large and Retail Trade; Car Repair and Motorcycle & 19.29 & 12.19 & -7.10 \\
\hline Vehicle, Storage, Information and Communication & 7.27 & 8.62 & 1.34 \\
\hline Procurement Accomodation, Foods, and Beverage & 3.40 & 3.52 & 0.12 \\
\hline Financial Service and Insurance & 0.55 & 0.28 & -0.26 \\
\hline Other Services & 5.65 & 10.39 & 4.74 \\
\hline Total & 100.00 & 100.00 & \\
\hline
\end{tabular}

Source: Processed, 2019.

In Table 5 above, it is crystal clear that the raw materials used most in economy of Jambi region in 1995 were raw materials derived from the wood industry sector, wood and cork goods and woven goods from bamboo, rattan with a proportion approximately $24,40 \%$. Furthermore in 2016, the intermediate input structure appears to have shifted to the plantation sector, which has a contribution of $25.43 \%$. The wood industry sector, goods from wood and cork and handmade goods from bamboo, rattan and the like declined $-21.79 \%$, until the remaining $2.61 \%$ contributed to the total primary input. The role of the industrial sector this year has shifted to the food, beverage and tobacco industries which have contributed to structure of primary inputs as much as $14.93 \%$. With the changing conditions of primary input structures such as this, it can be generalized that fiscal decentralization policies have a major impact on structural transformation in the primary input structure of Jambi Province, because there has been a shift in the composition of raw materials used in Jambi's economy, from the most industrial sector to sector plantation. But this change does not lead to the normal conditions stated by Chenery-Syrquin (1975), supposedly from the agricultural sector to the industrial sector. It means that fiscal decentralization has made the economic structure in Jambi, especially in the primary input structure, increasingly away from changes in normal economic structure. 
Table 6.

Change of Intermediate Output StructureBySectoralIn Jambi ProvincePeriod 1995 and 2016(\%)

\begin{tabular}{|l|c|c|c|}
\hline \multicolumn{1}{|c|}{ Sector } & \multicolumn{3}{c|}{ Intermediate Output } \\
\cline { 2 - 4 } & $\mathbf{1 9 9 5}$ & $\mathbf{2 0 1 6}$ & \multicolumn{1}{|c|}{$\Delta$ OA } \\
\hline Food Crops and Horticulture & 10.30 & 1.75 & -8.54 \\
\hline Plantation Plant & 13.01 & 23.16 & 10.16 \\
\hline Live Stock and Derivation Result & 1.95 & 0.17 & -1.78 \\
\hline Forestry and Logging & 9.43 & 0.66 & -8.77 \\
\hline Fishery & 0.80 & 5.74 & 4.95 \\
\hline Mining and Quarrying & 2.37 & 0.77 & -1.61 \\
\hline Coal Industry and Oil and Gas Refinery & 12.60 & 5.31 & -7.29 \\
\hline Food Industry, Beverageand Tobacco & 0.98 & 7.12 & 6.14 \\
\hline Textil, Leather Goods, Footwear & 0.16 & 0.46 & 0.30 \\
\hline Wood Industry, Goods From WoodandCork,danHandmadeSouvenirfrom Bamboo and Rattan & 8.53 & 0.54 & -7.99 \\
\hline Pulp industry, Goods from Pulp; Printing and Recording Media & 0.29 & 1.79 & 1.50 \\
\hline Chemistry, PharmacydanTraditional Medicine & 0.02 & 0.01 & -0.01 \\
\hline Rubber Industry, Goods from Rubber and Plastic & 1.16 & 3.10 & 1.94 \\
\hline Non-Metal Quarrying and Base Metal & 0.28 & 0.40 & 0.12 \\
\hline Metal Industry;Computer, Electronic, Optic; and Electricity Tools & 0.09 & 1.42 & 1.33 \\
\hline Another Industries & 0.07 & 0.21 & 0.15 \\
\hline Procurement for Electricity, Gas, Water, and Management of Trash, Waste, and Recycle & 0.55 & 0.30 & -0.25 \\
\hline Construction & 0.14 & 0.16 & 0.02 \\
\hline Large and Retail Trade; Car Repair and Motorcycle & 11.93 & 17.68 & 5.75 \\
\hline Vehicle, Storage, Information and Communication & 9.51 & 10.77 & 1.26 \\
\hline Procurement Accomodation, Foods, and Beverage & 5.02 & 4.47 & -0.55 \\
\hline Financial Service and Insurance & 3.68 & 0.64 & -3.03 \\
\hline Other Services & 7.17 & 13.37 & 6.20 \\
\hline Total & $\mathbf{1 0 0 . 0 0}$ & $\mathbf{1 0 0 . 0 0}$ & \\
\hline Source Processe & & \\
\hline
\end{tabular}

Source: Processed, 2019.

Different facts if observed in the intermediate output structure, as presented in Table 6 above. During the period of 1995 and 2016 the role of the plantation sector was very dominant as the sector that most distributes output to be used as an advanced product in the Jambi economy. In 1995, its contribution to the output structure reached $13.01 \%$, relatively higher than the coal and oil and gas refinery sector at $12.60 \%$. In 2016, its role strengthened with its contribution to formation of output reaching $23.16 \%$, exceeding the contribution of the trade sector which was the second largest at $17.68 \%$. It means there was no structural change in the composition of intermediate output Jambi Province during period 1995 and 2016. Since there was no change in the structure of intermediate outputin 1995 and 2016 periods, it is certain that the fiscal decentralization policy implemented did not have a strong influence on change intermediate output structure in Jambi Province.

Overall, input-output structure in the Jambi Province IO-R in 1995 and 2016, tended to experience significant changes. However, as indicated earlier, the change was not normal, because of the industrial and trade sectors in 1995 to agricultural sector in 2016. Jambi Province's input-output structure was very dominant in the wood industry sector, wood and cork goods and handmade goods from bamboo, rattan , and the trade sector, respectively at $17.10 \%$ and $17.51 \%$. While the agricultural sector, especially food crop and horticulture sector, and plantation sector respectively contributed only $10.47 \%$ and $8.51 \%$. But in 2016 , there was a shift in the economic structure, which was marked by the increasing contribution of the plantation sector to the composition of input-output to $23.18 \%$, and the decreasing contribution of wood industry sector, wood and cork and handmade goods from bamboo, rattan to $2.16 \%$, and the trade sector to $12.18 \%$. There is a trade off here, which should be from the agricultural sector to the industry, but which happens from the industrial sector to agricultural sector.

\section{Change of Multiplier Structure and Leading Sector}

In IO-R model the influence of economic interactions can be classified into three types, namely: (1) direct influence, (2) indirect influence, and (3) total influence. Direct effect is the effect directly felt by a sector whose output is used as input from the production of the sector concerned. While the indirect effect shows the indirect influence felt by a sector whose output is not used as input from the sector concerned. Finally, the effect of total or total effect is the overall influence in the economy where the sector in question is located. Based on these three influences, with the IO-R model we can trace wherever the output of a sector is distributed, and what inputs are used by the sector. 
Especially for total effect of a sector, it can be observed based on 2 (two) types of linkages, namely backward linkage effect (BLE) and forward linkage effect (FLE). Through BLE, it will be known how much the impact of production from a sector on the increase in production of other sectors behind which moves simultaneously as input in the regional economy. Whereas from FLE, it can be measured how much contribution from a sector in supporting the continuation of other production simultaneously which uses its output as input for advanced products. The following is explained the amount of BLE and FLE from each sector observed in Jambi Province IO-R in 1995 and 2016.

From 23 economic sectors observed, only food crop and horticulture sectors decreased in strength to attract other sectors behind. This phenomenon can be seen from the comparison between the value of the BLE multiplier in 1995 and 2016. In 1995 the value of the BLE multiplier in the food crop and horticulture sector was 1.4136, in 2016 it was 1.1056, which means a decrease of around $-1.04 \%$ per year for the period 1995 2016. The BLE value of 1.4136 in 1995 indicated that every time there was a final injection of demand (consumption, government expenditure, investment and exports) of 1 rupiah in the food crop and horticulture sectors, the total economic output values of the sectors behind them were interrelated as inputs simultaneously it will increase by 1.4136 rupiah. And for 1.1056 rupiah in 2016 for the same final demand injection.

The backward link between economic sectors in Jambi seems to increase and strengthen after the implementation of fiscal decentralization (2016). There are 10 economic sectors that record the highest increase in the value of BLE with a range per year for the period $1995-2016$ of $7.16-14.56 \%$ per year, namely: (1) metal goods, computers, electronics, optics, industrial sectors and electrical tools; (2) the sector of providing accommodation, food and beverage; (3) the rubber industry, rubber and plastic goods; (4) textile, leather goods, and footwear industries; (5) fisheries; (6) paper and paper goods industries; printing and recording media; (7) other services; (8) food, beverage and tobacco industries; (9) other processing industries; and (10) transportation (vehicle), warehousing, information and communication.

The results of the measurement of BLE multiplier between both periods above turned out to provide an illustration of the impact of fiscal decentralization in economy of Jambi region which is different from previously calculation. By using the BLE multiplier number, it turns out that most industrial sectors have a high BLE value in Jambi's economy in 2016. The changes also increased the most sharply between 1995-2016, compared to the agricultural sector. For example, the paper industry sector and goods from printing paper and recording media that have a BLE value far above the agricultural sectors, which amounted to 4.8795 points. Then, the increase was also the highest in 2016, which amounted to $9.90 \%$ per year, exceeding the growth of BLE in the agricultural sectors. In addition to the paper industry, other industrial sectors that have developed rapidly during the fiscal decentralization period are (1) the metal goods, computer, electronic, optical and electrical equipment sectors; (2) the rubber industry, rubber and plastic goods; and (3) the food, beverage and tobacco industry sector. These three sectors have a
BLE value which averages $9.77 \%$ per year during the period of fiscal decentralization. As for the agricultural sectors such as plantation crops, livestock, as well as forestry and logging, BLE growth has been slower, which is $2.34 \%$ per year. This final proposition means that quantitatively descriptive fiscal decentralization policies have a very strong impact on changes in the economic structure in Jambi Province, especially in the sectoral BLE multiplier structure.

\section{V.}

\section{CONCLUSION}

From aspect of the composition of raw materials used in the economy of Jambi there has been a shift from the industrial sector onto the plantation sector, in contrast to the pattern of changes in economic structure as in Chenery-Syrquin (1975). This condition illustrates that in the era of fiscal decentralization the structure of the economy in Jambi is seen from the structure of the primary input increasingly away from changes in the normal economic structure.Based on the assessment of multiplier backward linkage effect (BLE) on changes in the BLE multiplier structure of industrial sectors in Jambi economy that grew faster than the agricultural sector, it was ensured that structural transformation towards normal was in accordance with ChenerySyrquin'sstatement.

\section{REFERENCE}

[1] Amir, H., dan Nazara, S. 2005. Analysis of Structural Change (Economic Landscape) and Strategic Policy Development of East Java 1994 and 2000: Input Output Analysis. Journal of Development and Economics of Indonesia, Vol. 5(2), hal: 37-55..

[2] Statistics Bureau of Indonesia. 2000. Theory and Analysis :Input-Output Table. Central For Statistical Services. Jakarta.

[3] Budi, K. 2015. Analysis of Structural Change of Jambi Province. Master of Economic Program. FEB-UNJA, Jambi

[4] Chenery, H., and Syrquin, M. 1975. Patterns Of Development, 1950-1970. World Bank. Oxford University Press, Oxford.

[5] Daryanto, A.,danHafizrianda, Y. 2010. Input Output Analysis and Social Accounting Matrix for Regional Economic Development.IPB Press, Bogor.

[6] Fabiomarta W. 2004.Structural Transformation of Indonesian Economics and Factors Affecting . FEM Bogor Agricultural University, Bogor.

[7] Nazara S. 1997. Input Output Analysis .Publisher LP-FEUI, Jakarta

[8] Nazara S, dan Amir H. 2005. Analysis of Structural Change of Economy (economic landscape) and strategic policy East Java's Development 1994 and 2000 Input Output Analysis .Journal of Indonesian Economics Development FEUI Edition January 2005.

[9] Saraan S. 2006. Transformation Structural Analysis in Indonesia. Thesis Postgraduate North Sumatera University, Medan.

[10] Subagiyo E. 2009. Shift of Economics Structure and Disparity of Regional in Jambi Province A Study Before 
and After The Application Autonomy's Policy of Region, Jambi. Thesis postgraduate University of Jambi. 